\title{
Truthfulness of the Existence of the Pelusium Megashear Fault System, East of Cairo, Egypt
}

\author{
Mohamed A. Gamal \\ Geophysics Department, Cairo University, Cairo, Egypt \\ Email: mohgamal1@yahoo.com
}

Received August 15, 2012; revised September 17, 2012; accepted October 18, 2012

\begin{abstract}
The so-called Pelusium Megashear System (PMS), consists of echelon left-lateral megashears crossing Africa from the Nile-Delta since the Precambrian times. Although this system is questioned by some scientists, its existence is supported by others. This research work provides evidences for the existence of the PMS near Egypt's capital (Cairo city). Evidence is interpreted from gravity, magnetic, and seismological data, which proves that it has been in existence since $2800 \mathrm{BC}$ [1]. To support the existence of this fault zone system, all available tectonic data are reviewed; new magnetic tilt derivative TDR map and recent fault plane solution map are introduced. Moreover available earthquake catalogue for historical and recent occurrences in and around the Pelusium zone is compiled. The collected recent and historical seismicity data is supporting the existence of PMS system. The faults excluded from magnetic maps were found to be in a good agreement with tectonic and gravity data introduced by some authors. Available fault plane solutions for old and recent earthquakes gave rise to the hypothesis that the PMS is right lateral shear system. Additionally, the Pelusium zone is evaluated for the rate of seismic activity. The hazards of these zones are studied by calculating the earthquake recurrence rates using Richter-Gutenberg formula $(\operatorname{LogN}=a-b M)$. A statistical method is applied to exclude the effect of lack of data due to little seismograph station in the early records, or lack of population density. The Pelusium Megashear fault system proved to be active at least in Egypt, however, it plays a role only over big time window, may be thousands of years to dissipate stresses accumulated within the west of Sinai Peninsula in the African Eurasian-Arabian plates. Finally integrated tectonic model including the effect of PMS is introduced to solve the complexity of intraplate tectonics in Northern Egypt.
\end{abstract}

Keywords: Pelusium; Megashear; Fault; Hazard; Recurrence; Cairo; Egypt

\section{Introduction}

Although the continental interplate boundaries are well understood in Egypt (activity between plates), little is known about intraplate activities, or internal seismic activities inside the Egyptian territory. Using the available data in Egypt, including gravity data interpretation, total magnetic field data and seismicity, this paper sheds light on these intraplate activities. The initiation of new seismic source zones inside the Egyptian territory, based on the previous data, is a result of the present work. Egypt is facing great hazards since active seismic source zones are located near Egypt's most populous city, Cairo. This means that a catastrophe may occur in the near or far future, as old buildings and non-engineered constructions are abundant in areas such as Old Cairo, the ancient, surviving quarter of Egypt's capital. In this paper the PMS is introduced in North Africa, to help solve tectonic stresses and major earthquakes that exist inside the African plate. It could be treated as a distributer of the stresses accumulated in the eastern Mediterranean in al- most E-W direction. The net result is that, the Gulf of Suez couldn't be opened to its end to meet the Mediterranean's sea, West of Sinai Peninsula. This is probably because the red sea rift dies on another big but older NESW megashear system.

The northeast trending megalineaments cross the northern periphery of the Tibesti Massif, as well as northeastern trending faults (Touside fault) mapped by Alwashe 1978 [2], are interpreted as being components of the leftlateral PMS (Figures 1 and 2). In the Levant, this system includes the Qattara-Eratosthenes, Pelusium, and Dead Sea megashears and may also include the hinge line along the Mediterranean coast of Israel. All of these faults, which are very old features, merge northward into the "border zone" which separates the east and the west of Anatolia (Neev, 1975; Neev and Friedman, 1978) [4,5].

The extension of the PMS is northeast-southwest, crossing east of the delta and Cairo (Figure 2) and west of the Delta (Neev et al., 1982) [6].

In Northwest Sinai, lineaments represent a young, pro- 


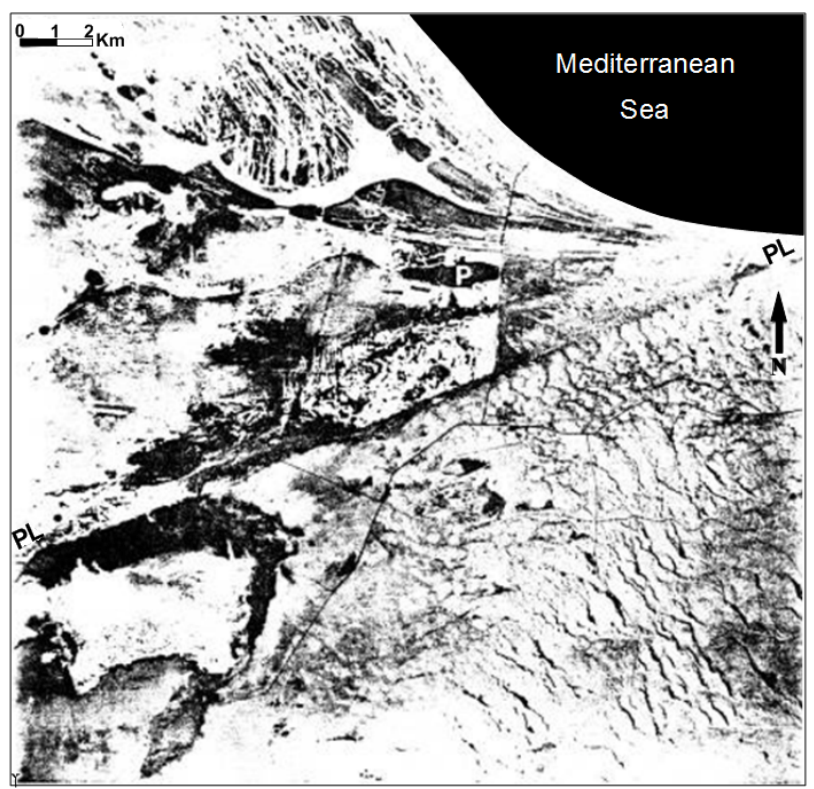

Figure 1. Arial photograph showing a segment of the Pelusium line (marked PL-PL) at eastern fringe of the Nile Delta (Neev et al., 1982 [6]). bably rejuvenated, tectonic fracture system, which is related to the coastal hinge line, as well as to the Pelusium line. Figure 2 shows the Pelusium line where it enters Northwest Sinai. Similar indications for recent movements (Neev et al., 1982 [6]) are the abrupt termination of the northwest trending fault system which takes place along a segment of the proposed line between El Bahariya and Fayium depressions (Said, 1962) [7].

In general, the regions of Northeast Africa and the Northwest Arabian are considered as a complex component of the overall Gondwana history. For example some scientists found that searching the western boundary of Sinai Peninsula is time wasting. The northern sector of Northeast Africa records the evolution of Paleotethys, Neotethys and the Mediterranean Sea. Each of the phases of intracontinental rifting in Africa produced extensive, deep basins there, and the pulses of compressional deformation are readily recognizable (Guiraud and Bosworth, 1999) [8]. The northern Red Sea-Gulf of Aqaba junction is considered to be the youngest plate boundary to develop in the Gondwana realm and has established the present kinematic framework of the Africa-Arabia

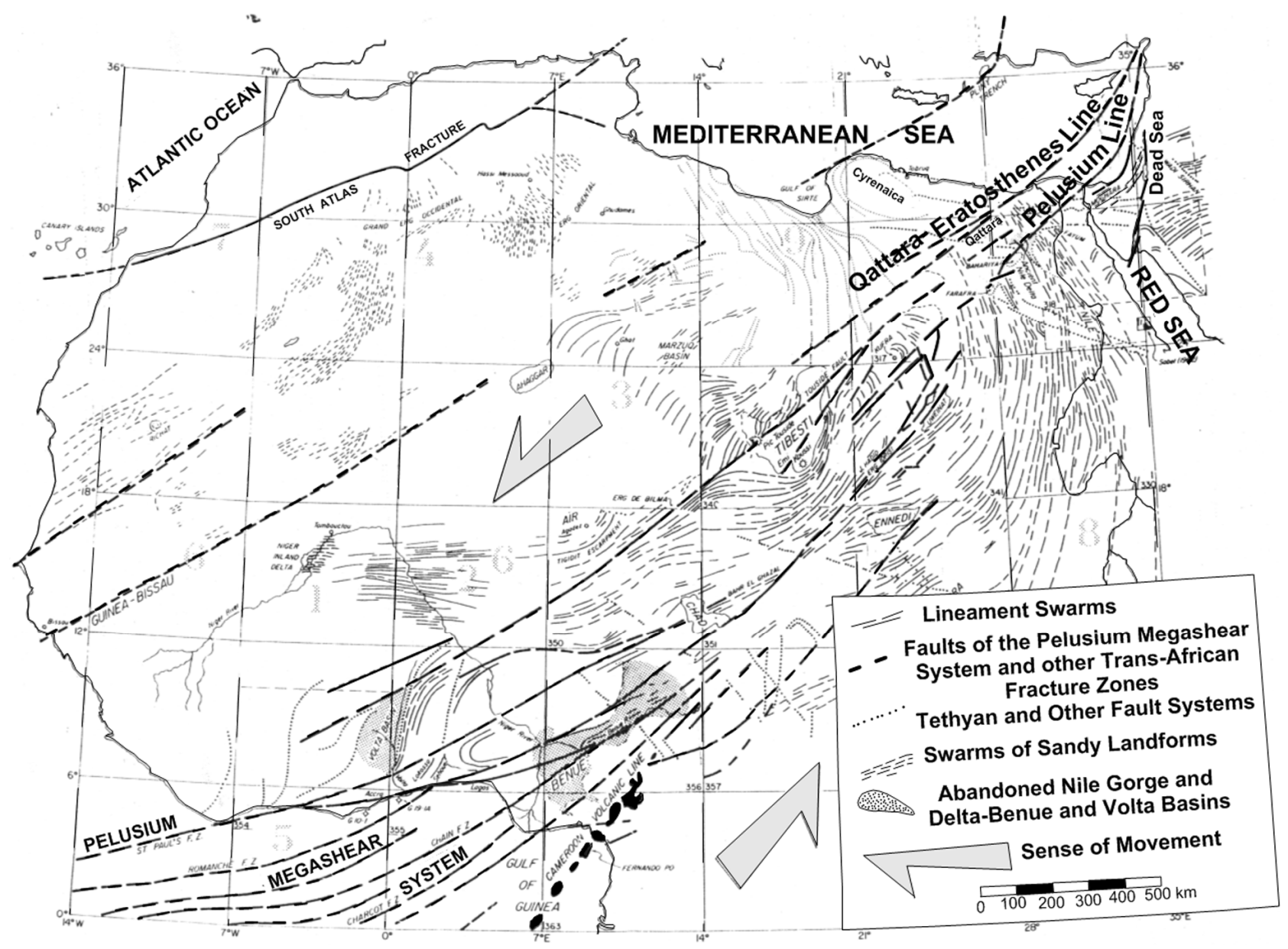

Figure 2. Distribution pattern of the geosutures and lineament swarms of PMS crossing Africa, in NE-SW direction at both sides of the Nile delta east of Cairo (Neev et al., 1982 [6]). 
system. Several syntheses of the geology and paleogeography of Northeast Africa and Arabia are now available (Guiraud and Bosworth, 1999) [8].

\section{Major Historical Earthquakes}

Historical seismicity is the best evidence for the existence of the PMS. The PMS is thought to be active since 4811 years ago. Evidence from the ancient Egyptians times (Pharonic ages) documented that this system is capable of producing earthquakes since 2800 Years BC. Figure 3 shows the historical and important earthquakes in and around PMS, where the PMS, as detected from this study, is also shown. For example in 2800 BC. an earthquake occurred at Sharquia province, east Nile delta, deep fissures and soil cracks were reported at Tell Basta, about $16 \mathrm{~km}$ east-southeast of Zagazig city WoodwardClyde consultants, 1985) [11]. Another Example is 1754 earthquake which occurred East of Cairo at Tanta area (Woodward-Clyde consultants, 1985) [11]. The earthquake was Felt over an area of approximately 150,000 square $\mathrm{km}$. The description involved that two-thirds of old houses in Cairo were heavily damage and conesquently thousands of people were killed and injured. The last example of PMS earthquakes is the 1847 earthquake which occurred in Faiyum. A total of 85 people were killed, 62 were injured in Faiyum, 3000 houses and many mosques were destroyed. In middle Egypt, 27 people were killed. In Cairo, 100 people were killed and thousands of houses were destroyed, but European-style houses resisted damage. Moreover, thousands of people were injured and thousand of houses were damaged around the whole country. Damages and injuries were also reported in Alexandria (Woodward-Clyde consultants, 1985) [11]. Based on historical seismicity and nature of seismic activity the Pelusium megashear system can be divided into the following three main zones.

\subsection{Northern Pelusium Zone}

This source zone contains the set of events that hit the eastern Mediterranean coast, which includes the coasts of Syria, Lebanon, Israel and Asia minor coast (Figure 1). Historical records extending back to $590 \mathrm{BC}$, at which events may cause a tsunami at the Lebanese coast. The events in this source zone are most probably accompanied by flooding, in addition to destruction. A good example is the event on July 9, 551 along the coast of Beirut, which possessed a maximum intensity of Io $=$ XI-XII and with a local magnitude $\mathrm{ML}=7.8$, and caused de-

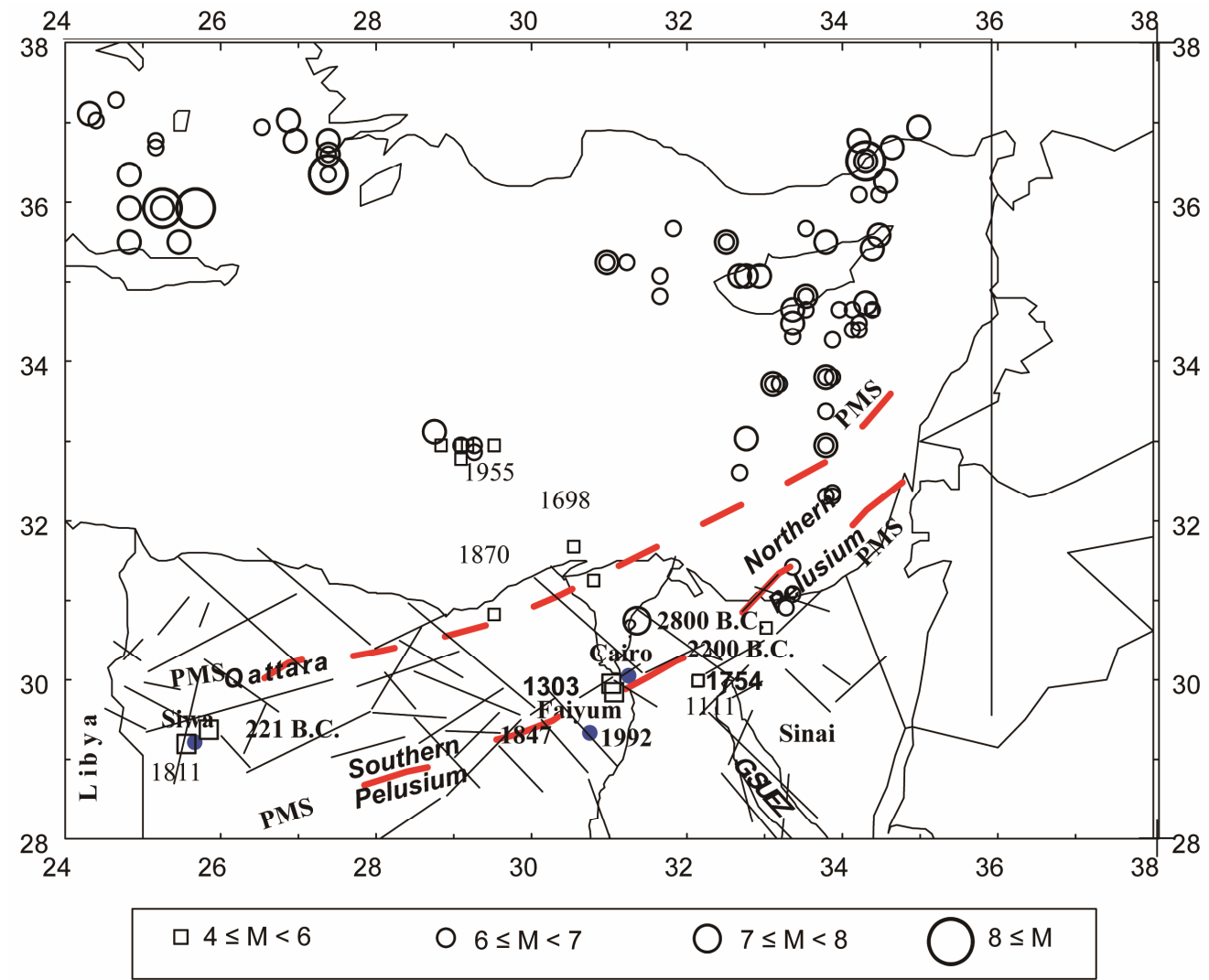

Figure 3. Historical and important earthquakes, triggered by PMS in the time period (2800 BC-1995 AD). (PMS = is PMS as detected from this study, Thin lines = shear faults detected from gravity). (Integrated from, Maamoun, 1979 [19]; Maamoun et al., 1984 [1]; Ben-Menahem, 1979 [9]; Riad et al., 1983 [13] and Woodward-Clyde consultants, 1985) [11]. 
struction in the cities of Sur, Sidon, Tripoli and was also felt in Egypt. Consequently, it generated a tsunami at the same time (Ben-Menahem, 1979) [9].

\subsection{Southern Pelusium Zone}

This zone includes the set of events in the east and south of the Nile delta. Historically, the events of this zone are dated back to 4811 years ago, for which a good example is the large earthquake that occurred in $2800 \mathrm{BC}$ at Sharquia province, east of the Nile delta, according to Sieberg, 1932 [10]. The event is described historically to have occurred at the region of King Aktoes (10th Dynasty), as severe earthquake occurred in the northern part of Egypt. Deep fissures and soil cracks were reported at Tell Basta, about $16 \mathrm{~km}$ east-southeast of the city of Zagazig. These manifestations gave a maximum intensity of VII and near this village a chasm (huge hole) opened at Bubastis and many perished. The data was dated, 2800 BC (Woodward and Clyde Consultant, 1985) [11]. This source zone also contains the important group of events that occurred near the city of Faiyum, (60 km from Cairo). One example is the event of August 8, 1303 which is located in the Fayium region (Figure 3) which was accompanied by great damages in Cairo, where several mosques were destroyed (Sieberg, 1932) [10]. Another example of the events of the southern Pelusium zone is the event on August 7, 1847. This event is one of the largest-known events that occurred in the Nile valley, and was felt over nearly the whole area of Egypt; killed 212 people and destroyed thousands of houses in the country, except those of the European-style (Maamoun et al., 1984) [1].

Recent seismicity is also recorded from this active zone and the earthquake of October, 1992 is one example. Because of its proximity to crowded Cairo, it caused much damage than expected (Body wave magnitude $\mathrm{Mb}$ $=5.9$ ), especially to old buildings. The earthquake occurred south of Cairo in Dahsour, 350 building collapsed completely and 9000 suffered irreparably damages, killing 545 and injuring 6512. Additionally, 50,000 people became homeless. The idea of the existence of this source zone (i.e. the Southern Pelusium Zone) solves the controversial problem of the origin of such important earthquakes that hit Egypt. These earthquakes were not clearly understood before and were not directly related to plate boundary activity in Egypt.

\subsection{Qattara Zone}

Events have been reported to occur in this zone since 320 AD (Maamoun et al. 1984) [1] with moderate seismicity and effects. It seems that the most predominant effect of this source zone reaches offshore Alexandria (Figures 3). The most important event that reached this zone was on September 12, 1955 with ML $=6.6$ and maximum inten- sity Io = IX (Ben-Menahem, 1979) [9]. Damage had been reported in the Nile Delta between Alexandria and Cairo. The tremor was felt in the entire eastern Mediterranean basin (Rothe, 1969) [12]. The 22 lives, which were lost, were considered victims of panic rather than of the earthquake itself, while the 300 buildings collapsed in Rashid, Idku, Damanhur, Mahmodya and Abu Hommos were of older brick construction.

\section{The Pelusium Megashear Systems as Detected from Gravity and Magnetic Data}

Riad et al., 1983 [13] has indicated that the juxtaposition of relatively high gravity anomalies against low-anomaly features and vice versa, particularly along zones of high gravity gradients, "can only occur when shear movements are acting on previously faulted formations" (Figure 3).

Meshref, 1990 [14] found that the magnetic anomalies in north Egypt are aligned along definite axes forming tectonic trends. Some of these trends (North-East) are a result of the Pelusium megashear system (tectonic events affected the basement, Figure 4.

The magnetic data of north Egypt are extracted from the world wide project "Magnetic Anomaly Map of the World" (EMAG2, Maus et al., 2009) [15], compiled from satellite, airborne, and marine magnetic anomaly information, supplemented by anomaly values derived from oceanic crustal ages (Figure 4). The resolution of the data varies from place to place and depends on the source of the data. In some areas it is a $1-\mathrm{km}$ grid interval and in other areas it is $5-\mathrm{km}$ grid spacing which is accepted in our regional study (North Egypt). It is well kwon that the magnetic trends do not occur at random but are rather aligned along definite and preferred axes that can be used to define magnetic provinces (Affleck, 1963) [16]. The magnetic anomaly map (Figure 4) shows regional trends in NE directions, southern the Nile Delta. In order to enhance and separate these magnetic trends from the magnetic data, Tilt Derivative (TDR) technique was applied to the data. The TDR is estimated by calculating the vertical and horizontal derivatives of the total magnetic field.

The most important advantage of the TDR (Figure 4) is that its zero contour line is located over or close to the edges of the contacts (faults). The effect of the Pelusium megashear can be traced from the TDR map as shown in Figure 5. Euler method was also applied to the gridded magnetic data in order to estimate the location of the magnetic sources which means in our study the sources of faulting (Reid et al., 1990) [17]. Figure 5 shows the expected sources of faulting.

Magnetic data shows three main fault trends (Figure 5):

- The Pelusium Fault trend,

- The Qatarra fault trend, and 

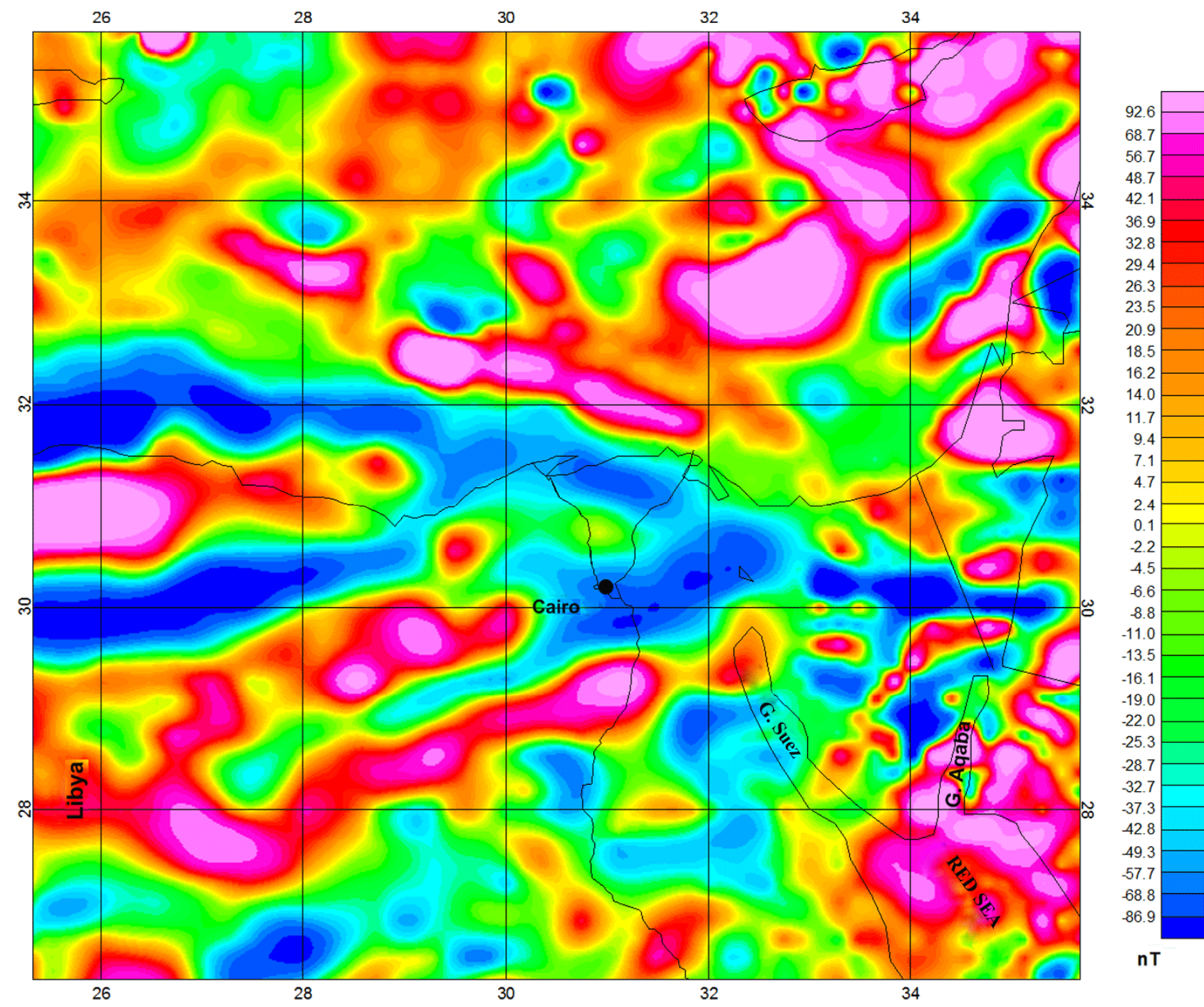

Figure 4. Total magnetic field map of northern Egypt, (EMAG2 project, Maus et al., 2009) [15]. Showing high magnetic anomalies in the southeastern part of the Nile Delta. (nT = Nano Tesla the unit of magnetic measurement).

- The Galala-Cairo fault trend.

All these fault trends contribute to the dissipation of stresses in NE-SW or nearly E-W direction (Figures 5).

\section{Recurrence of Earthquakes in the Pelusium Zones}

Kebeasy, 1990 [18] studied the distribution of earthquake epicenters (historical and recent), and suggested that the activity tends to occur along three main seismically active trends. These trends are: Northern Red Sea-Gulf of Suez-Cairo-Alexandria Clysmic trend, the Levant-Aqaba trend and East Mediterranean-Cairo-Faiyum Pelusiac trend. He considered the Pelusiac (PMS) is a trend that possesses small to moderate historical and recent earthquakes and that the foci are confined within the crust (Figure 6).

A modified and updated earthquake catalogue for his- torical and recent earthquake seismicity that affected the Pelusium zone and surrounding areas has been compiled, to evaluate the rate of seismic activity inside PMS and its surrounding (Figure 7). The compiled catalogue is based on the following catalogues:

1) For the period 2200 BC-1899: Maamoun, 1979 [19]; Maamoun et al., 1984 [1]; Ben-Menahem, 1979 [9] and Woodward-Clyde consultants, 1985 [11].

2) For the period 1899-1996: Makropoulos and Burton, 1981 [20]; Maamoun et al., 1984 [1]; Ben-Menahem, 1979 [9]; Woodward-Clyde consultants, 1985 [11]; Riad and Meyers, 1985 [21]; Shapira, 1994 [22] and NEIC, 2007 [23].

To evaluate the recurrence rate, or rate of seismicity, we have to define the PMS active source zones. The first step and perhaps one of the most basic steps in a seismic hazard is the definition of the seismic source zones. 


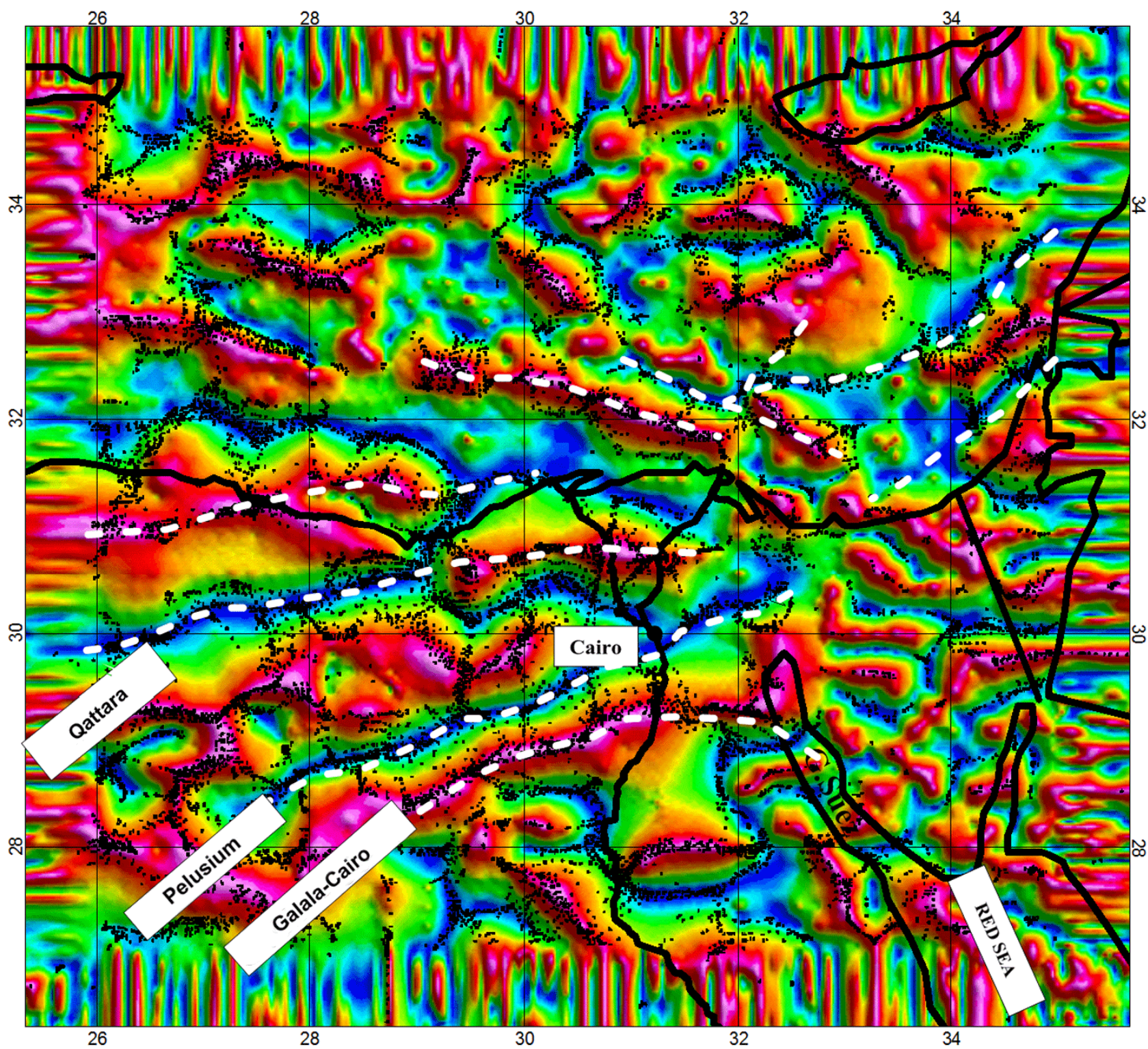

Figure 5. Tilt derivative map extracted from the total magnetic field for North Egypt. Colored anomalies $=$ TDR map, Black dots = Euler solution locations (contacts or faults) and white hachured line = Interpreted Pelusium Megashear, Qattara and Galala-Cairo faults from both TDR and Euler methods.

Shape and location of seismic source zones could affect the particular location at which the hazard is being evaluated. Defining and understanding seismic sources is often the major part of a seismic hazard analysis and requires good knowledge of the regional and local geology, seismicity, and tectonics which are considered as the essential clues towards the seismic source delineation.

To separate the Pelusium source zone (Figure 7), the concepts of regional tectonics were followed using available geological maps, earthquake epicenter distribution and active fault trends suggested in this study (Figures 5 and 7). The observed seismic activity at or near the Pelusium faults was the dominant parameter in identifying this active seismic source zones.

The seismic source regionalization methodology is utilized here, for the assessment of the earthquake recurrence (frequency of magnitudes) for the Pelusium seismic sources and hence determining the hazards coming from this active systems east of Cairo (Figure 7). We have separating the Pelusium zone into Northern and southern Pelusium based on the different rate of seismicity. The well known Gutenberg-Richter relation, 1944 [30] was used to find the earthquake frequency,

$$
\log \mathrm{N}=\mathrm{a}-\mathrm{bM},
$$

where $\mathrm{M}$ is the magnitude, $\mathrm{N}$ is the number of earthquakes and (a) and (b) are constants to be established for 


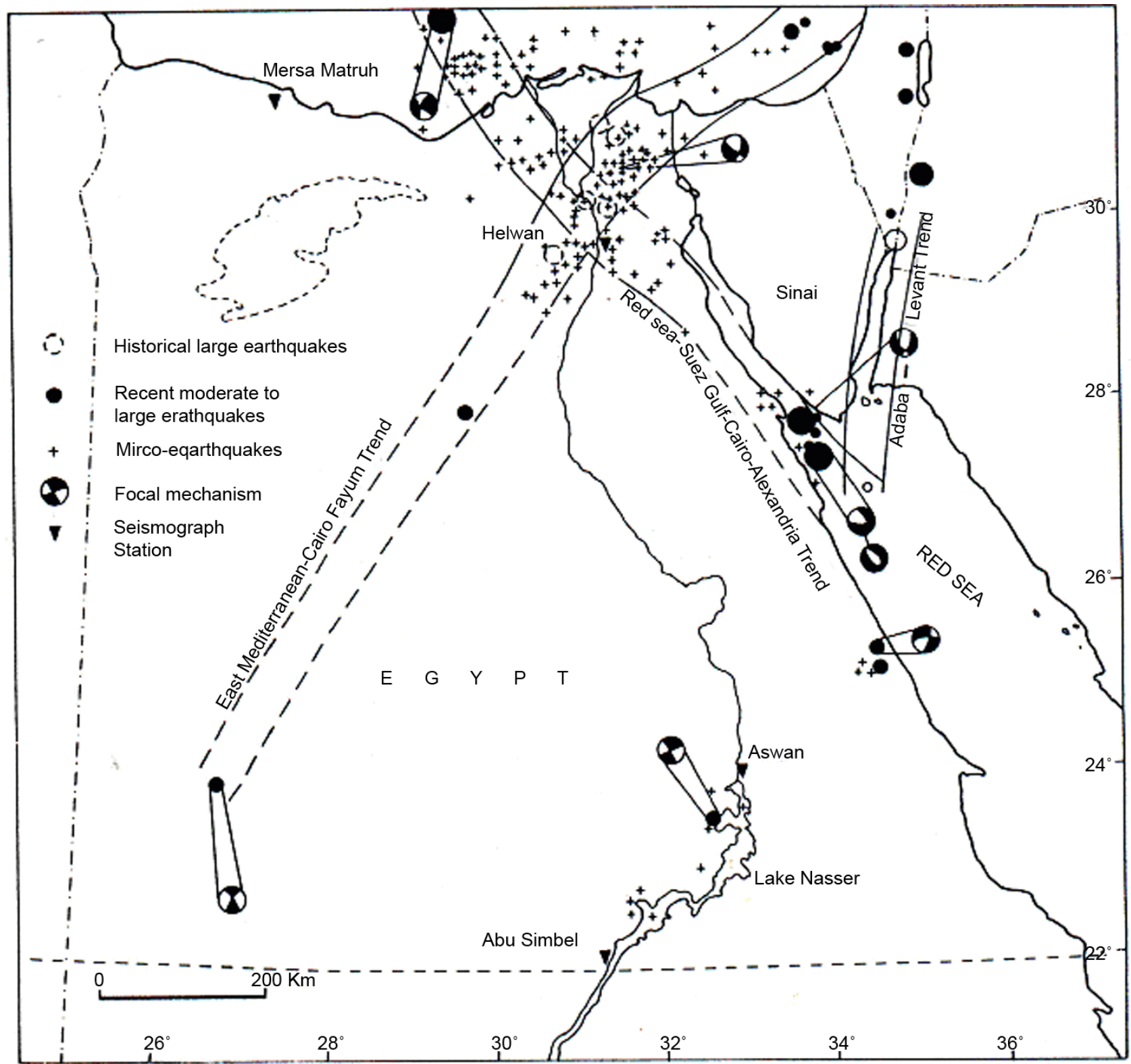

Figure 6. The Pelusium, Levant and Clysmic trends as described by Kebeasy 1990 [18].

both North and Southern PMS zones (Figure 7). The formula has been shown to hold for microearthquakes (Sanford and Holmes, 1962) [31] and for microfractures (Mongi, 1962) [32]. Before applying the previous formulas we used the Stepp's method (Stepp, 1973) [33] to statistically complete the data since it appeared to be incomplete when we tried to fit the formula (it also can be seen from the gap of seismicity in between the northern and southern Pelusium in Figure 7). This incomplete data is due to lack of data reporting in the early periods as no stations were available at that time. Table 1 presents the estimated regression constants of formula (1) and gives the return periods of intermediate and big earthquakes in the Pelusium zone east of Cairo.
The rate of seismicity in the PMS is found to be relatively low. An earthquake of $M \geq 6$ is repeated every 162 years in the Southern Pelusium and 229 years in the Northern Pelusium zone. Important and Major earthquakes of magnitude $M \geq 7$ were found to be occur in thousands of years. Although PMS is an important active seismic source zone Near Cairo city, it is considered as a Calm active source zone capable of producing big earthquakes but in long term of time in hundreds or thousands of years.

For small earthquakes of $M \geq 5$ the recurrence rate proved to be valid at our time. For example, Faiyum area which is located in the Southern Pelusium zone, is capable of producing earthquakes every 20 years. This was 


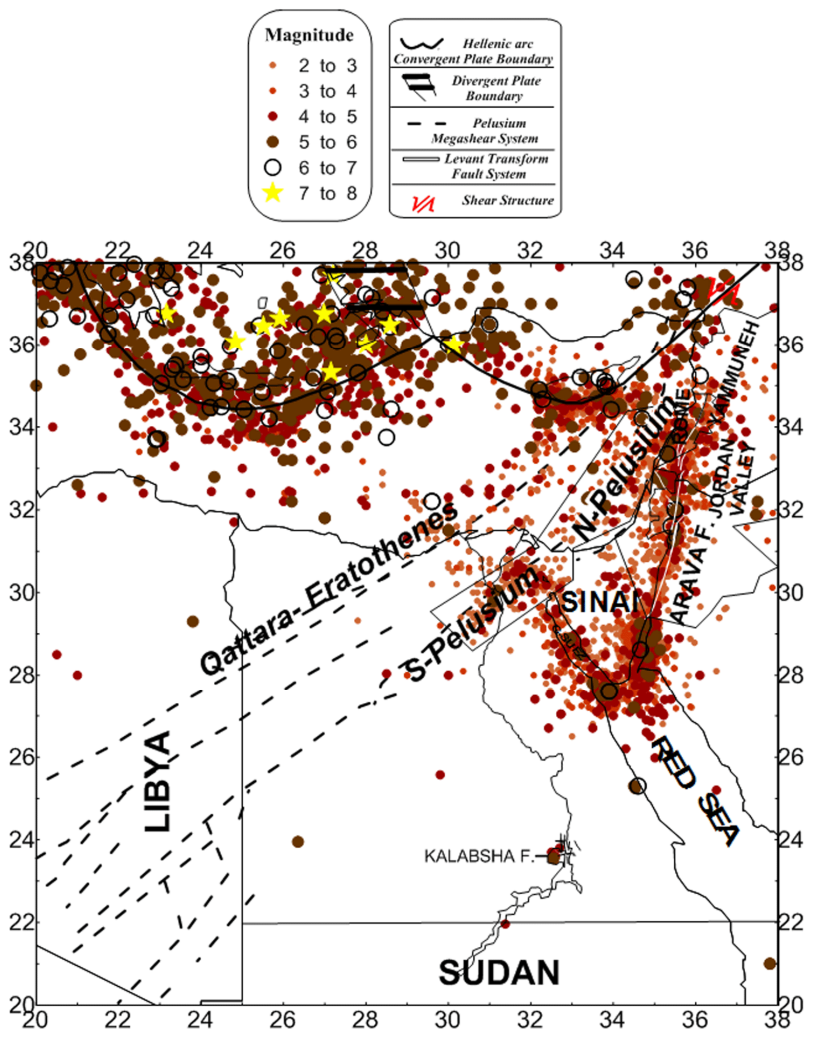

Figure 7. Correlation of the recent and historical seismicity in the period 1900-2011 with the Neo-tectonic elements of the Pelusium and surrounding areas. Integrated from, McKenzie 1972 [24]; Shapira 1994 [22]; Shapira and Shamir, 1994 [25]; Neev et al., 1982 [6]; Makropoulos and Burton, 1981 [20]; Maamoun et al., 1984 [1]; Ben-Menahem 1979 [9]; Woodward-Clyde consultants, 1985 [11]; Riad and Meyers , 1985 [21]; NEIC and USGS, 2007 [23].

Table 1. The estimated return periods of earthquakes in the region East of Cairo City per years.

\begin{tabular}{|c|c|c|c|c|}
\hline Const (a) & Const (b) & $\begin{array}{l}\text { Return Period } \\
\text { (Years) } M \geq 5\end{array}$ & $\begin{array}{l}\text { Return Period } \\
\text { (Years) } M \geq 6\end{array}$ & $\begin{array}{l}\text { Return Period } \\
\text { (Years) } \mathrm{M} \geq 7\end{array}$ \\
\hline \multicolumn{5}{|c|}{ Sothern Pelusium Zone } \\
\hline 2.77 & 0.83 & 23 & 162 & 1096 \\
\hline \multicolumn{5}{|c|}{ Northern Pelusium Zone } \\
\hline 2.62 & 0.83 & 33 & 229 & 1548 \\
\hline
\end{tabular}

evidenced at least in the last 40 years as detected from local observations.

\section{Integrated Tectonic Model for Northern Egypt}

Figure 8 shows new integrated tectonic map for Egypt and surrounding areas. The tectonics and, therefore, the seismotectonics of northern Egypt are very complex. They involve the relative motion between the three main plates, Eurasian-Arabian, African and the European plates.
The tectonic framework of Northern Egypt can be divided into four seismotectonic units (Figure 8) as follows:

1) Subduction at the Eastern Mediterranean,

2) Temsah \& Eratosthenes Norhern activity,

3) Activity at the Northern Red sea and,

4) The Pelusium-Qattara shear Systems.

\subsection{Subduction at the Eastern Mediterranean}

The hypothesis that the African lithospheric plate underthrusts the Eurasian lithospheric plate at the Greek island of Crete where the African lithosphere is consumed into the mantle was discussed by different authors Mckenzie, 1970, 1972 [24,34]; Dewey et al., 1973 [35]; Papazachos, 1973 [37]; Rotstein and Kafka, 1982 [38]; Wong et al., 1971 [34]; Hsu and Ryan, 1972 [35]; Finetti and Morelli, 1973 [36]; Lort et al., 1974 [42]; Stride et al., 1977 [38]; Gass and Masson, 1963 [39]; and Voget and Higgs, 1969 [40].

Papazachos and Comninakis, 1971 have defined the subduction to occur in The Aegean (Hellenic) arc and, its general features in the Mediterranean as an active part of the Alpide-Himalayan-Melanesian belt. It constitutes one of the two continental fracture systems of the earth. The sedimentary part of this arc is the southern section of the Dinaric Alps, and it includes the main mountain range of Greece Peninsula, the mountains of Crete, and the Dodecanese Islands. This region is the most active seismic region in Europe and contains volcanoes, which were active in historic times, and solfatara fields (Figure 8).

The subduction zones present beneath Cyprus and Crete, where the African plate is dipping northward beneath the southern part of the Eurasian continent are characterized by earthquakes of large magnitudes that have had history of affecting Egypt (Maamoun et al., 1984 [1]; Ben-Menahem, 1979 [9]; Karnik, 1969 [47]. Frequent earthquakes of magnitude 7 or greater occur as often as five or six times per century (Ambraseys, 1981 [48]). These earthquakes have reportedly caused damage in Cairo and have been felt along the lower Nile valley more than 500 $\mathrm{km}$ from their epicenters (Figure 7). Various plate tectonics models, for the eastern Mediterranean region have been proposed by McKenzie, 1972 [24]; Dewey et al. 1973 [35], Papazachos, 1973 [37]; and Papazachos et al., 1993 [49]. Papazachos, 1990 [50]; and Papazachos et al., 1991 [51]; comprehensively identified the basic features of the seismotectonics of the Aegean, based on historical and recent earthquake activity and fault plane solutions of shallow and intermediate earthquakes. Papazachos, 1990 [50], has observed that the foci of intermediate depth earthquakes form two dipping parts of the seismic Benioff zone with clearly different dipping angles. The first part dips slightly $\left(10^{\circ}\right)$ and corresponds to the inner slope of the sedimentary part of the Hellenic arc (subduction 


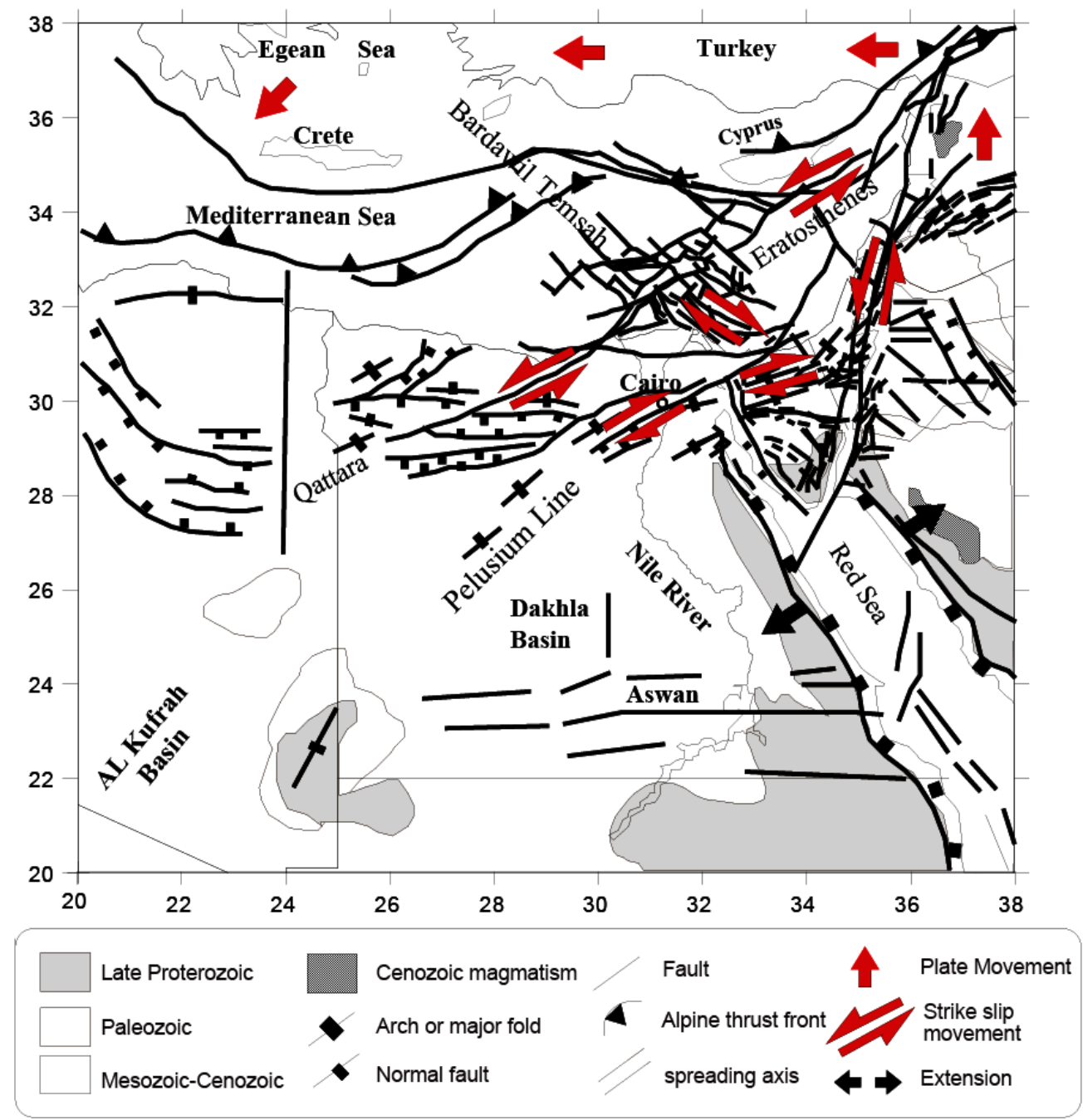

Figure 8. Integrated Tectonic model for northern Egypt showing relative motion of PMS and surrounding zones including Subduction at the Eastern Mediterranean, Temsah \& Eratosthenes Norhern activity, Activity at the Northern Red sea and, The Pelusium-Qattara shear Systems. Modified from Barazangi et al., 1993 [27]; Salmon et al., 1996 [28]; =Guiraud and Bosworth, 1999 [8]; Abdel Aal et al., 2000 [29].

front). All large intermediate earthquakes occur along this front, probably due to the coupling between the eastern Mediterranean lithosphere (part of the African lithospheric plate) with the Aegean lithosphere (front part of the Eurasian lithospheric plate). The second part of the Benioff zone, in accordance with Papazachos nd Comninakis, 1971 [46]; and Comninakis and Papazachos, 1980 [52], dips steeply $\left(38^{\circ}\right)$ below the volcanic arc and is the result of the subduction of the front part of the eastern Mediterranean lithosphere without any coupling with the Aegean lithosphere explaining the lower seismicity of this zone. Some studies show the exact deformation styles using swath mapping and seismic reflection profiling for the Mediterranean Ridge (e.g. Huguen et al., 2001 [53]). Some other studies (e.g. Gert Kahle et al., 1998 [54] and Mahmoud, 2003 [55]) estimates the exact rate of relative motion of Northern Africa relative to Europe using GPS network stations.

\subsection{Temsah Eratosthenes Northern Activity}

During 3-D seismic acquisition, of $7000 \mathrm{~km}^{2}$ of shipboard, gravity data, and high resolution aeromagnetic data, Abdel Aal et al., 2000 [29] introduced another type of motion affecting the offshore of the Nile Delta in the form of two main intersecting oblique slip faults (Figure 8). He postulated an oceanic crust, with maximum age of old as Late Paleozoic/Early Triassic or as young as Upper Cretaceous. Three main complex fault trends were excluded. The NW-SE isfaq-Bardawil (Temsah) fault trend, the NE-SW Qattara-Eratosthenes (Rosetta) fault trend, and the E-W faults delineating the Messinian salt basin (Figure 8).

These trends were found parallel the circum-Mediterranean plate boundaries, and considered old inherited ba- 
sement faults that reactivate periodically throughout the development of the area. Fault movement were proposed to be late Cretaceous, and that was indicated by the onlap of source rock prone late Cretaceous and early Tertiary deepwater sediments. The NE-SW (Rosetta) trend shows large-scale structural relief created by transpressional movement along the Qattara-Eratosthenes trend. Fault movement was considered late Cretaceous. The movement is contemporaneous with oblique subduction of Africa along the Cyprus trench. Some faults were described as structurally governed and seems controlled and triggered by deep-seated basement faults (Abdel Aal et al., 2000 [29]).

\subsection{Activity at the Northern Red Sea}

The Red Sea-Gulf of Aden rift system has long been recognized as having been formed by the separation of Arabia from Africa (Lartet, 1869 [56]; Robson 1971 [57]; Chenet and Letouzey 1983 [58]; and Steckler 1985 [59]; Coleman, 1974 [60]; Gass 1977 [61]; and Cochran, 1983 [62]) and is perhaps the best modern example of continenttal fragmentation and incipient ocean formation. These depressions were formed by the anticlockwise rotation of Arabia away from Africa about a pole of rotation in the central or south-central Mediterranean Sea (McKenzie et al., 1970 [63]; Freund 1970 [64]; Le Pichon and Francheteau, 1978 [65]).

The opening of the Red Sea is split between the opening of the Gulf of Suez and predominantly sinistral shear along the Gulf of Aqaba-Dead Sea rift system (the Levant transform fault system). The opening of the Gulf of Suez is proposed to be earlier than the left lateral transform fault in the leavant system (Ben Menahem et al. 1976 [66], Freund, 1965 [67]; and Girdler and Styles, 1974 [68]). The opening of the Red Sea is totally about 190 km, (McKenzie et al., 1970 [63]; and Girdler and Styles, 1974 [68]). While sinistral movement along the Dead Sea rift is approximately $107 \mathrm{~km}$ (Quennell, 1959 [69]; and Freund, 1970 [64]). The opening of the Gulf of Suez accounts for only a few kilometers and the rift is not underlain by oceanic crust (Garfunkel and Bartov, 1977 [70]).

One possible constraint upon extension in the northern Red Sea and Gulf of Suez is provided by the complementary shear movements along the Gulf of Aqaba and the Dead Sea rift system (Lartet, 1869 [56]; Dubertret, 1932 [71]; Quennel, 1958 [72]; 1959 [69]; 1984 [73]; Freund, 1970 [64]; and Freund et al., 1970 [74]). Offset of Miocene sedimentary and volcanic rocks was taken to indicate about $45 \mathrm{~km}$ of post-Miocene movement with an additional $62 \mathrm{~km}$ of movement thought to have occurred in the early Miocene, possibly related to the initial faulting in the Gulf of Suez and Red Sea rifting. The amount of $107 \mathrm{~km}$ of left-lateral offset has subsequently been corroborated by a corresponding offset of aeromagnetic anomalies (Hatcher et al., 1981 [75]). Two or more phases of opening of the Red Sea, possibly Correlating with poly-phase movement on the Dead Sea system, was suggested by Girdler and Styles, 1974 [68]; 1976 [68]; Richardson and Harrison, 1976 [77]; and Girdler, 1985 [78]. Cochran 1983 [62]; and Labrecque and Zitellini 1985 [79], however, doubted this suggestion. It seems reasonable still to use the amount of shear on the Dead Sea system $(107 \mathrm{~km})$ as a constraint on opening of the Red Sea and Gulf of Suez. Ben-Menahem et al., 1976 [66], further concluded that the opening of the Red Sea is partly absorbed as a left-lateral component between Arabia and Sinai along the Dead Sea transform fault, while the rest of the motion is taken up by a combination of a left-lateral slip and an opening along the Suez line. Opening Models, activity at the northern Red Sea and crust type are discussed in details by Gamal, 1997 [26].

\subsection{The Pelusium and Qattara Shear Systems}

It was early that Neev 1975 [4], proposed that northeast Africa consists of two distinct sub-plates, separated by a compressional fault zone he referred to as the "Pelusium Line". This line was mapped largely on the basis of geophysical and remote sensing data to extend offshore and parallel to the Levant margin, passing onshore at the Roman town of Pelusium in Egypt (Figure 1), and continuing to the southwest through Bahariya and the Kufra Basin (Figure 2). The concept was later elaborated as the PMS, envisioned to extend from the Anatolian convergent front, across Africa to the Gulf of Guinea, there linking to the equatorial Atlantic fracture zones and continuing to South America (Neev et al.,1982 [6]). The megashear was believed to have originated in the Precambrian, with repeated reactivations as a sinistral transpressive fault zone. Some authors have incorporated the Pelusium concept in their paleogeographic interpretations of NE Africa (Keeley, 1994 [80] and El Hawat, 1997 [81]). Guiraud and Bosworth, 1999 [8], suggest that the Pelusium megashear played no more than a minimal role in plate-scale dynamics, based on the interpretations of reflection seismic data, which do not show the existence of any thoroughgoing, NE-SW-striking faults (Mosconi et al.,1996 [82]). However the imaged strata are generally of Eocene to Recent age, and did not go deep to the upper crust at which no oil industry or seismic data were taken. In a direct contradiction, Hussein and Abd-Allah, 2001 [83], found that in the northern part of the Eastern Desert deformation of the Jurassic-Cretaceous rocks increases southward. They considered this as a result of southward thinning of rocks. The thick sequence found in the north was attributed to the stresses by inter- and intragranular deformations (Figure 9).

They realized that so intensively deformed zone in the 
north part of the eastern desert related to the Nile Delta hinge zone and that the Jurassic-Cretaceous rocks in the northern Western Desert are deformed by southwarddipping east-west-orientated faults (Moustafa et al., 1998 [84]).

The northern parts of the Eastern Desert and Sinai are affected by northwest to north-dipping east-west to eastnorth-east-orientated faults. The accommodation zone between these two sets of faults, which are dipping opposite to each other, is expressed by several northwestelongated horst and graben blocks in the Nile Valley area (Figure 9 Hussein and Abd-Allah, 2001 [83]).

Similarly, Moustafa et al., 1985 [85], 1998 [84]; Moustafa and Khalil, 1994 [86], found Faults of east-west set are abundant in northern Egypt and have dextral diagonal-slip movement. The northeast elongated folds of the Syrian Arc deformations in this area extend due east in northern Sinai and due west in northern Western Desert (Figure 9). Again Similar fold trends were traced by Garfunkel and Goudarzi, 1980 [87] in eastern Libya and by Neev 1975 [4], in Turkey and Syria.

It is worth mentioning here that most of the faults in the east and west of the Nile Delta show right lateral strike slip motion (Figure 9).

Although Neev, 1975 [4] suggested that the pelusium megashear system is a leftlateral strike slip system, recent collected fault plane solutions for earthquakes occurred in northern Egypt in the time period 1974-2007 (El-Sayed et al., 1999 [88]; Mahmoud, 2003 [55]; Ba- dawy, 2001, 2003 [89-90] and Abou Elenean, 2007 [91]), suggest normal, right lateral or oblique slip movement (Figure 10). The rightlateral sense of motion, is in a good agreement with the model of Hussein and Abd-Allah, 2001 [83] (Figure 9).

The Gulf of Suez seems to continue opening not to the north, but dissipating stresses diagonally in NE-SW direction along PMS (Figures 10 and 11). The Pelusium, Qattara and Galala-Cairo shear systems seem to be taking the stresses from the Northern red sea into NE-SW directions (Figure 5).

\section{Conclusions}

The tectonics and seismotectonics of Northern Egypt are very complex. It can be considered as result of the interactions of interplate activities (African, Eurasian-Arabian and European plates) and intraplates interaction (Pelusim, Qattara and Cairo-Galala). Activity in northern Egypt can be divided into four main seismotectonic zones:

1) Subduction at the Eastern Mediterranean,

2) Temsah \& Eratosthenes Norhern activity,

3) Activity at the Northern Red sea and,

4) The Pelusium-Qattara shear Systems.

The intraplate activities (PMS) were found to be responsible for most important activities inside Egypt as a result of its proximity to urban communities. It is responsible for small but risky earthquakes such as the Faiyum, 1992 earthquake. This kind of earthquakes, although

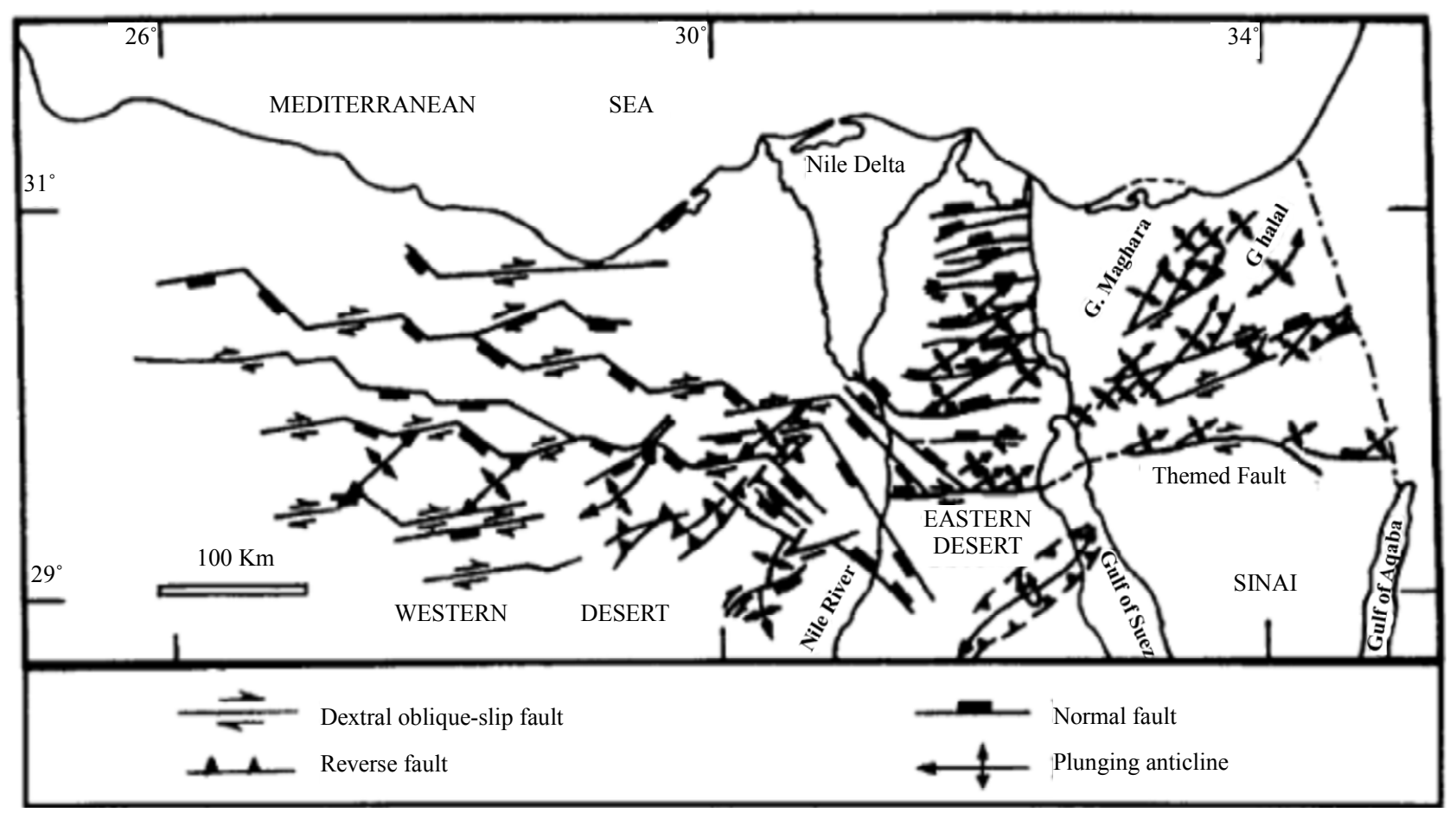

Figure 9. Northeast-dipping faults in the Eastern Desert and southward-dipping faults in the Western Desert in the Nile Valley area (Hussein and Abd-Allah [83], 2001 and Moustafa et al., 1998). 


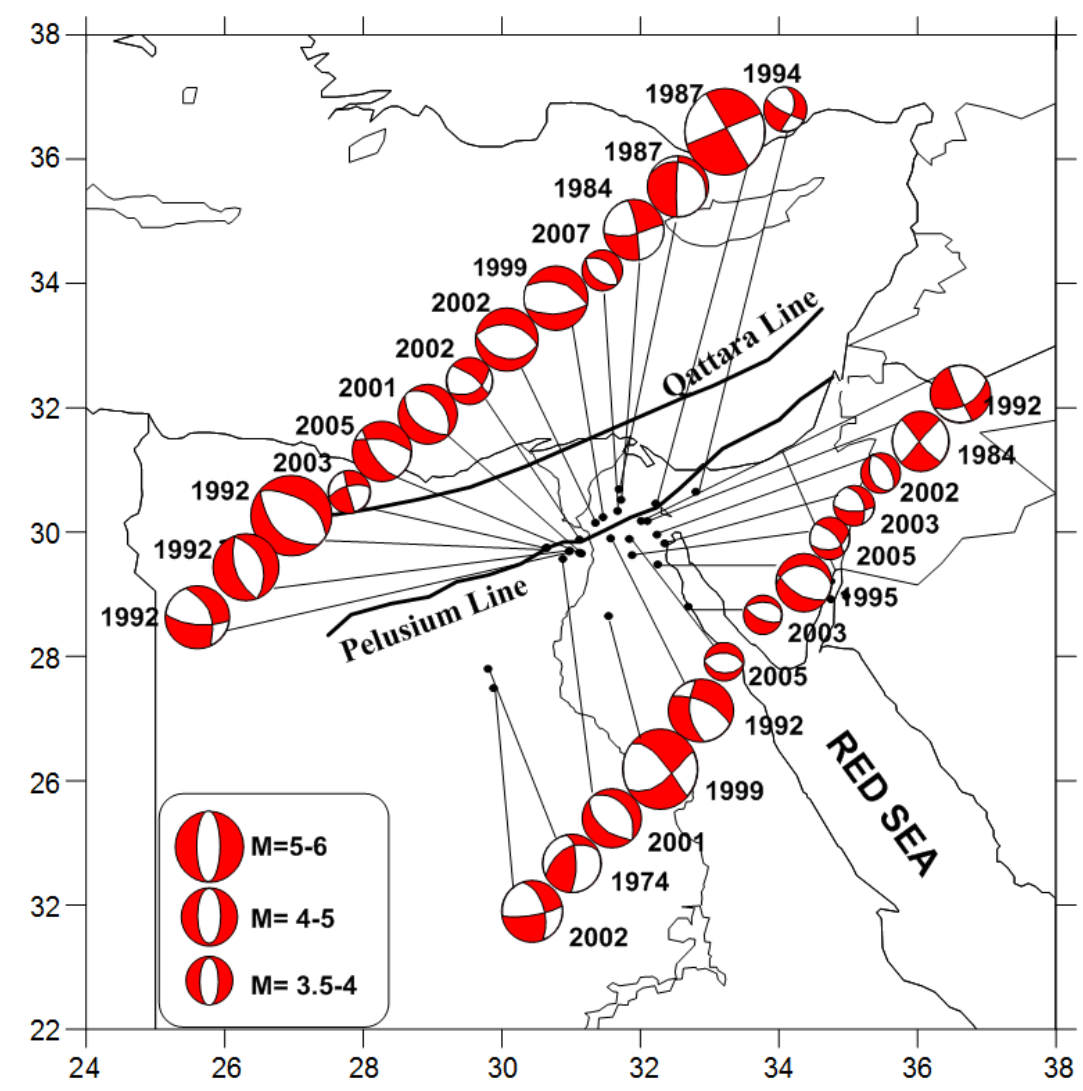

Figure 10. Recent fault plane solutions for earthquakes occurred in and around the Pelusium zone, in the time period 1974-2007. Most trends are the normal (NW-SE F. plane) or right lateral (NE-SW F. plane) FPS. The right lateral fault plane is Parallel to the Pelusium line (NE-SW). Black lines = Pelusium faults detected from this study (Integrated from El-Sayed $e t$ al., 1999 [88]; Mahmoud, 2003 [55]; Badawdy, 2001 [89], 2003 [90] and Abou Elenean, 2007 [91]).

small compared to other earthquakes that affected Egypt $(\mathrm{Mb}=5.9)$, is responsible for high highest causalities and maximum risk in Egypt in the last 100 year, because of its proximity to highly populated areas and old houses.

The intraplate activities (PMS) are the most effective tectonic activities inside Egypt because of its nearness to urban communities, which is concentrated mainly around the Nile-Valley. The hidden source or reason for disguising seismic activities inside Egypt, is the Pelusium, Qattara and Galala-Cairo shear systems or simply PMS (Figure 7).

Most of the stresses along the Red Sea-Gulf of Suez zone are dissipated through the NE-SW shear zones (Figure 11) of the Pelusium, Qattara and Galala-Cairo trends. Perhaps it gives reason why the opening of the Red Sea did not continue to reach the Mediterranean Sea. This is because the opening of the Red Sea dies on another older shear system, which is the PMS (Figure 8).

The present Seismological, gravity and magnetic data support the existence of active tectonic zones. The PMS, Qattara and Galala-Cairo trends in northern Egypt. Based on historical records PMS proved to be active since 4811 years. However, the rate of activity is low-to-moderate activity. The excluded rate of occurrences for moderate earthquake magnitude $M \geq 5$ is found to be nearly 23 years. This was confirmed from damage reports of recent earthquakes (e.g. 12 October, 1992 Faiyum). While an earthquake of $M \geq 6$ is repeated every 162 years in the southern pelusium and 229 years in the Northern Pelusium zone. Major earthquakes of magnitude $M \geq 7$ also occurred but in terms of thousands of years.

Based on these calculations, certainly Cairo and especially Old Cairo will be suffering a catastrophic incident in the near or far future. In other words if an earthquake of magnitude $\mathrm{M} \geq 7$ did not occure since 1096 year (Table 1), most probably it will occure now. Moreover, this is evidenced historically. In 1754, a severe earthquake occurred east of Cairo and two thirds of Cairo was destroyed, and thousands died. These big tremors were felt for 40 days and that the advance of the sea submerged half of the town of Alexandria (Ambraseys, 1961 [92]).

The analysis of historical earthquakes and data completeness for different earthquake magnitudes in these active zones, supports the existence of PMS. Many recent and historical earthquakes that affected these zones where considered before intraplate activity, or earthquakes with no explanation (e.g. 12 October, 1992 Faiyum). The idea of the existence of this source zone 


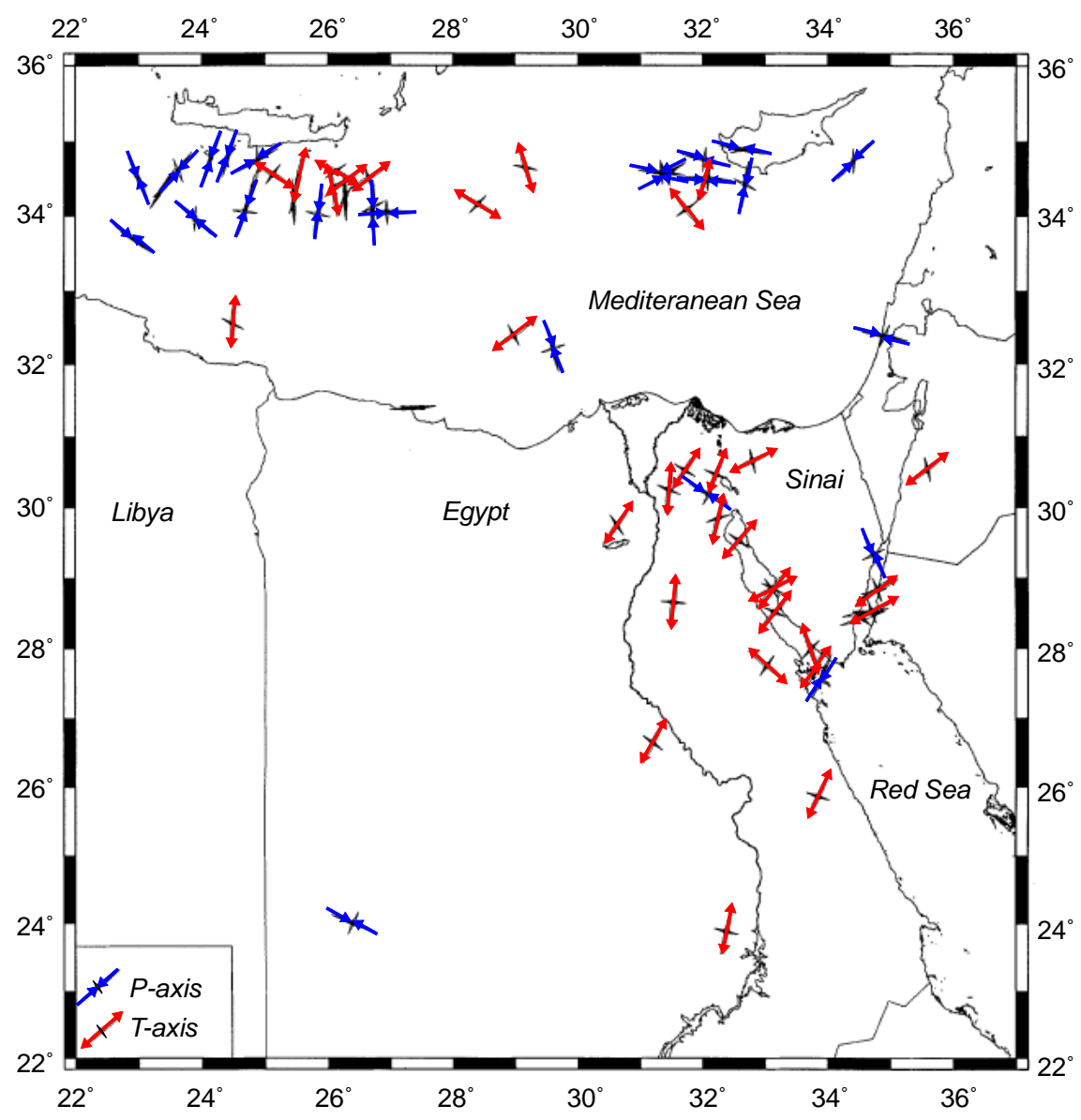

Figure 11. Spatial distributions of the stress axes derived from the focal mechanisms of moderate to large earthquakes. Principal compression and tension is indicated (Mahmoud, 2003 [55]).

solves the controversial problem of the origin of such important earthquakes striking Egypt. These earthquakes were not clearly understood and were not directly related to plate boundary activity in Egypt. More detailed analysis is needed to support the proposed work for the importance of such plate boundary that may affect the most populated areas inside Egypt including its capital, Cairo. PMS is a very important active seismic source zone Near Cairo city, it is considered as a Calm active source zone capable of producing big earthquakes but in long term may be hundreds or thousands of years. However, for small earthquakes $M \geq 5$ the recurrence rate is about 20 years. Care must be taken since such small earthquakes affect the old buildings present in the Old-Cairo area. Because of its nearness these small earthquakes have very high risk for Old-Cairo City.

\section{REFERENCES}

[1] M. Maamoun, A. Megehed and A. Allam, "Seismicity of Egypt," Institute of Astronomy and Geophysics, 1984.

[2] M. Alwashe, "Luftbild- und Satellitenbild-Interpretation des lithologischen und teltonischen Baus in Nördlichen
Tibesti-Gebirge (Ehi Me'che' und Tirenno)," Berliner Geowissenschaftliche Abhandlungen: Reihe A, Vol. 5. 1978.

[3] N. N. Ambraseys, "Studies in Historical Seismicity and Tectonics, in the Environmental History of the Near and Middle East Since the Last Ice Age," Academic Publisher, New York, 1978, pp. 185-210.

[4] D. Neev, "Tectonic Evolution of the Middle East and the Levantine Basin (Eastern Most Mediterranean)," Geology, Vol. 3, No. 12, 1975, pp. 683-686. doi:10.1130/0091-7613(1975)3<683:TEOTME >2.0.CO;2

[5] D. Neev and G. M. Friedman, "Late Holocene Activity along the Margins of the Sinai Subplate," Science, Vol. 202, No. 4366, 1978, pp. 427-429. doi:10.1126/science.202.4366.427

[6] D. Neev, K. Hall and J. M. Saul, "The Pelusim Megashear System across Africa and Associated Lineament Swarms," Journal of Geophysical Research, Vol. 87, No. B2, 1982, pp. 1015-1030. doi:10.1029/JB087iB02p01015

[7] R. Said, "The Geology of Egypt," Elsevier, New York, 1962.

[8] R. A. Guiraud and W. Bosworth, "Phanerozoic Geodynamic Evolution of Northeastern Africa and the Northwestern Arabian Platform," Tectonophysics, Vol. 315, No. 
1-4, 1999, pp. 73-108. doi:10.1016/S0040-1951(99)00293-0

[9] A. Ben-Menahem, "Earthquake Catalogue for the Middle East (92 B.C.-1980 A.D.)," Bollettino di Geofisica Teorica ed Applicata, Vol. 21, No. 84, 1979, pp. 245-310.

[10] A. Sieberg, "Utersuchungen uber Erdbebengeographie," In: B. Gutenberg, Ed., Afrika-Handbuch der Geophysik, Berlin, 1932, pp. 864-881.

[11] Woodword Clyde Consultant, "Earthquake Activity and Dam Stability for the Aswan High Dam, Egypt," High and Aswan Dames Ministry of Trregation, Cairo, 1985.

[12] J. P. Rothe, "Moyen-Orient et Africa du nord," UNESCO, Mission d'Information Seismlogique, 1969, p. 45.

[13] S. Riad, H. A. EL-Etr and A. Mokhles, "Basement Tectonics of Northern Egypt as Interpreted from Gravity Data," International Basement Tectonics Association Publication, Vol. 4, 1983, pp. 209-231.

[14] W. M. Meshref, "Tectonic frame work in the Geology of Egypt Rushdi Said,” Egyptian General Petroleum Corporation, Conco, 1990, pp. 113-154.

[15] S. Maus, et al., "EMAG2: A 2-Arc min Resolution Earth Magnetic Anomaly Grid Compiled from Satellite, Airborne, and Marine Magnetic Measurements," Geochemistry, Geophysics, Geosystems, Vol. 10, No. 8, 2009, Article ID: Q08005, doi:10.1029/2009GC002471

[16] J. Affleck, "Magnetic Anomaly Trend and Spacing Patterns," Geophysics, Vol. 28, No. 3, 1963, pp. 379-395. doi:10.1190/1.1439188

[17] A. B. Reid, J. M. Allsop, H. Granser, A. J. Millet and I. W. Somerton, "Magnetic Interpretation in Three Dimensions Using Euler Deconvolution," Geophysics, Vol. 55, No. 1, 1990, pp. 80-91. doi:10.1190/1.1442774

[18] R. M. Kebeasy, "Seismicity Rushdi Said," A. A. Balkema, Rotterdam and Brookfield, 1990, pp. 51-59.

[19] M. Maamoun, "Macroseismic Observations of Principal Earthquake in Egypt," Helwan Institue of Astronomy and Geophysics, Bulletin, Vol. 183, 1979, p. 120.

[20] K. C. Makropoulos and P. W. Burton, "A Catalogue of Seismicity in Greece and Adjacent Areas," Geophysical Journal of Royal Astronomical Society, Vol. 65, No. 3, 1981, pp. 741-762. doi:10.1111/j.1365-246X.1981.tb04881.x

[21] S. Riad and H. Meyers, "Earthquake Catalog for the Middle East Countries 1900-1983," World Data Center, 1985.

[22] A. Shapira, "Seimological Bulletin of Israel, 1900-1994," 1994.

[23] NEIC and USGS, "Prelimenary Determination of Epicenters, Monthly Listing," US Department of the Interior/ Geological Survey, National Earthquake Information Center, 2007.

[24] D. P. McKenzie, "Active Tectonics of the Mediterranean Region," Geophysical Journal of the Royal Astronomical Society, Vol. 30, No. 2, 1972, pp. 109-185. doi:10.1111/j.1365-246X.1972.tb02351.x

[25] A. Shapira and G. Shamir, "Seismicity Parameters of Seismogenic Zones in and Around Israel," Report No. Z1/567/79(109), The Institute for Petroleum Research and geophysics, 1994.

[26] M. A. Gamal, "Regional Seismic Hazard Studies in Egypt,” M.Sc. Thesis, Cairo University, Cairo, 1997.

[27] M. Barazangi, D. Seber, T. Chaimov, J. Best, R. Litak, D. Al-Saad and T. Sawaf, "Tectonic Evolution of the Northern Arabian Plate in Western SYRIA," In: E. Boschi, et al., Eds., Recent Evolution and Seismicity of the Mediterranean Region, Academic Publishers, Kluwer, 1993, pp. 117-140. doi:10.1007/978-94-011-2016-6_5

[28] A. Salamon, A. Hofstetter, Z. Garfunkel and H. Ron, "Seismicity of the Eastern Mediterranean Region: Perspectivefrom the Sinai Subplate," Tectonophysics, Vol. 263, No. 1-4, 1996, pp. 293-305. doi:10.1016/S0040-1951(96)00030-3

[29] A. Abdel Aal, A. El Barkooky, M. Gerrits, H. Meyer, M. Schwander and H. Zaki, "Tectonic Evolution of the Eastern Mediterranean Basin and Its Significance for Hydrocarbon Prospectivity in the Ultradeepwater of the Nile Delta," Shell Egypt Deepwater BV (Egypt): The Leading Edge, 2000.

[30] B. Gutenberg and C. F. Richter, "Frequency of Earthquakes in California," Bulletin of the Seismological Society of America, Vol. 34, No. 4, 1944, pp. 185-188.

[31] A. R. Sanford and C. R. Holmes, "Microearthquakes near Socorro, New Mexico," Journal of Geophysical Research, Vol. 67, No. 11, 1962, pp. 4449-4459. doi:10.1029/JZ067i011p04449

[32] K. Mongi, "Study of the Elastic Shocks Caused by the Fracture of Heterogeneous Materials and Its Relation to Earthquakes Phenomena," Bulletin of the Earthquake Research Institute, Vol. 40, 1962, pp. 125-173.

[33] J. C. Stepp, "Analysis of Completeness of the Earthquake Sample in the Puget Sound Area," In: S. T. Handing, Ed., Contributions to Seismic Zoning, NOAA Technical Report ERL 267-ESL 30, US Department of Commerce, 1973.

[34] D. P. McKenzie, "Plate Tectonics of the Mediterranean Region," Nature, Vol. 226, 1970, pp. 239-248. doi: $10.1038 / 226239 \mathrm{a} 0$

[35] J. F. Dewey, W. C. Pitman, W. B. F. Ryan and J. Bonnin, "Plate Tectonics and the Evolution of the Arabian Plate System," Geological Society of America Bulletin, Vol. 84, No. 10, 1973, pp. 3137-3180.

doi:10.1130/0016-7606(1973)84<3137:PTATEO $>2.0 . C O$ , 2

[36] J. F. Dewey and C. Sengor, "Aegean and Surrounding Regions, Complex Multiplate and Continuum Tectonics in a Convergent Zone," Geological Society of America Bulletin, Vol. 90, 1979, pp. 84-92. doi:10.1130/0016-7606(1979)90<84:AASRCM>2.0.CO; $\underline{2}$

[37] B. C. Papazachos, "Distribution of Seismic Foci in the Mediterranean and Surrounding Area and Its Tectonics Implications," Geophysical Journal. Royal Astronomical Society, Vol. 33, No. 4, 1973, pp. 421-430. doi:10.1111/j.1365-246X.1973.tb02377.x

[38] Y. Rotstein and A. L.Kafka, "Seismotectonics of the Southern Boundary of Anatolia, Eastern Mediterranean Region," Journal of Geophysical Research, Vol. 87, No. 
B9, 1982, pp. 7694-7706.

[39] H. Wong, E. F. K. Zarudzki, J. D. Phillips and G. K. F. Giermann, "Some Geophysical Profiles in the Eastern Mediterranean," Geological Society of America Bulletin, Vol. 82, 1971, pp. 91-99. doi:10.1130/0016-7606(1971)82[91:SGPITE]2.0.CO;2

[40] J. K. Hsu and W. B. F. Ryan, "Summary of the Evidence for Extension and Compressional Tectonics in the Mediterranean," Initial Reportsk, Deep Sea Drilling Project 13, 1972, pp. 1011-1019.

[41] I. Finetti and C. Morelli, "Geophysical Exploration of the Mediterranean Sea," Bollettino di Geofisica Teorica ed Applicata, Vol. 15, 1973, pp. 263-340.

[42] J. M. Lort, W. A. Limond and F. Gray, "Preliminary Seismic Studies in the Eastern Mediterranean," Earth and Planetary Science Letters, Vol. 21, No. 4, 1974, pp. 355366. doi:10.1016/0012-821X(74)90174-5

[43] A. H. Stride, R. H. Belderson and N. H. Renyon, "Evolving Miogeaniclines of the East Mediterranean (Hellenic Calabrian and Cyprus Outer Ridges)," Philosophical Transactions of the Royal Society of London. Series A, Vol. 284, No. 1322, 1977, pp. 255-285.

[44] I. G. Gass and D. Masson-Smith, "The Geology and Gravity Anomalies of the Troodos Massif, Cyprus," Philosophical Transactions of the Royal Society of London, Vol. 255, No. 1060, 1963, pp. 417-467. doi:10.1098/rsta.1963.0009

[45] P. R. Voget and R. H. Higgs, "An Areomagnetic Survey of the Eastern Mediterranean Sea and Its Interpretation," Earth and Planetary Science Letters, Vol. 5, 1969, pp. 439-448. doi:10.1016/S0012-821X(68)80077-9

[46] B. C. Papazachos and P. E. Comninakis, "Geophysical and Tectonic Features of the Aegen Arc," Journal of Geophysical Research, Vol. 76, No. 35, 1971, pp. 85178533. doi:10.1029/JB076i035p08517

[47] V. Karnik, "Seismicity of the European Area, Parts 1 and 2," Academia Publishing House of the Czechoslovak Academy of Sciences, Prague, 1969.

[48] N. N. Ambraseys, "On the Long-Term Seismicity of the Hellenic Arc," Bollettino di Geofisica Teorica ed Applicata, Vol. 23, No. 92, 1981, pp. 355-359.

[49] B. C. Papazachos, C. H. A. Papaioannou, B. N. Margaris and N. P. Theodulidis, "Regionalization of Seismic Hazard in Greece Based on Seismic Sources," Natrual hazard, Vol. 8, 1993, pp. 1-18.

[50] B. C. Papazachos, "Seismicity of the Aegean and Surrounding area," Tectonics, Vol. 178, 1990, pp. 287-308.

[51] B. C. Papazachos, A. A. Kiratzi and E. E. Papadimitriou, "Regional Focal Mechanisms for Earthquakes in the Aegean Area," Pure and Applied Geophysics, Vol. 136, No. 4, 1991, pp. 405-420. doi:10.1007/BF00878578

[52] P. E. Comninakis and B. C. Papazachos, "Space and Time Distribution of the Intermediate Depth Earthquakes in the Hellenic Area," Tectonophysics, Vol. 70, 1980, pp. 35-47. doi:10.1016/0040-1951(80)90278-4

[53] C. Huguen, J. Mascle, E. Chaumillon, J. M. Woodside, J. D. Benkhelil, A. Kopfe and A. Volkonska1a, "Deformational Styles of the Eastern Mediterranean Ridge and Sur- roundings from Combined Swath Mapping and Seismic Ref Lection Profiling," Tectonophysics, Vol. 343, No. 1, 2001, pp. 21-47.

[54] H. Gert Kahle, C. Straub, R. Reilinger, S. McClusky, R. King, K. Hurst, G. Veis, K. Kastens and P. Cross, "The Strain Rate Field in the Eastern Mediterranean Region, Estimated by Repeated GPS Measurements," Tectonophysics, Vol. 294, No. 3-4, 1998, pp. 237-252. doi:10.1016/S0040-1951(98)00102-4

[55] S. M. Mahmoud, "Seismicity and GPS-Derived Crustal Deformation in Egypt," Journal of Geodynamics, Vol. 35, No. 3, 2003, pp. 333-352. doi:10.1016/S0264-3707(02)00135-7

[56] L. Lartet, "Essay on the Geology of Palestine," Geological Society of France, Vol. 1, 1869, pp.17-18.

[57] D. A. Robson, "The Structure of the Gulf of Suez (Clysmic) Rift, with Special Reference to the Eastern Side," Geological Society of London, Vol. 127, No. 3, 1971, pp. 247-276. doi:10.1144/gsjgs.127.3.0247

[58] P. Y. Chenet and J. Letouzey, "Tectonique de la Zone Comprise Entre Abu Durba et Gebel Nezzazat (Sinai, Egypt) Dans le Context de l'Evolution du Rift de Suez,' Bulletin des Centre de Recherches Exploration-Production Elf-Aquitaine, Vol. 7, 1983, pp. 201-215.

[59] M. S. Steckler, "Uplift and Extension at the Gulf of Suez, Indication of Induced Mantle Convection," Nature, Vol. 317, No. 6033, 1985, pp. 135-139. doi:10.1038/317135a0

[60] R. G. Coleman, "Geologic Background of the Red Sea," In: C. A. Burke and C. L. Drake, Eds., The Geology of Continental Margins, Springer, Berlin, 1974, pp. 743751.

[61] I. G. Gass, "The Evolution of the Pan-African Crystal Line Basement in NE Africa and South Arabia," The Geological Society of London, Vol. 134, No. 2, 1977, pp. 129-138. doi:10.1144/gsjgs.134.2.0129

[62] J. R. Cochran, "A Model for Development of Red Sea," American Association of Petroleum Geologists, Vol. 67, 1983, pp. 41-60.

[63] D. P. McKenzie, D. Davies and P. Molnar, "Plate Tectonics of the Red Sea and East Africa," Nature, Vol. 226, No. 5242, 1970, pp. 243-248. doi:10.1038/226243a0

[64] R. Freund, "Plate Tectonics of the Red Sea and East Africa," Nature, Vol. 228, 1970, p. 453. doi:10.1038/228453a0

[65] X. Le Pichon and J. Francheteau, "A Plate Tectonics Analysis of the Red Sea-Gulf of Aden Area," Tectonophysics, Vol. 46, No. 12, 1978, pp. 369-406 doi:10.1016/0040-1951(78)90214-7

[66] A. Ben-Menahem, A. Nur and M. Vered, "Tectonics, Seismicity and Structure of the Afro-Eurasian Junction of an Incoherent Plate," Physics of the Earth and Planetary Interiors, Vol. 12, No. 1, 1976, pp. 1-50.

[67] R. Freund, "A Model for the Structural Development of Israel and Adjacent Areas Since Upper Cretaceous Times," Geological Magazine, Vol. 102, No. 3, 1965, pp. 190-205. doi:10.1017/S0016756800053218

[68] R. W. Girdler and P. Styles, "Two Stages in the Red Sea Floor Spreading," Nature, Vol. 247, No. 5435, 1974, pp. 


\section{7-11. doi:10.1038/247007a0}

[69] A. M. Quennell, "Tectonics of the Dead Sea Rift," The International Geological Congress, Session 20, 1956.

[70] Z. Garfunkel and Y. Bartov, "The Tectonics of the Suez rift," Bulletin of Geological Survey of Israel, Vol. 71, No. 44, 1977, pp. 1-48.

[71] L. Dubertret, "Les Forms Structurales de la Syrie et de la Palestine, Leur Origin," Comptes Rendus des Seances de I Academie des Sciences, Vol. 195, 1932, pp. 65-66.

[72] A. M. Quennell, "The Structure and Evolution of the Dead Sea Rift," Quarterly Journal of the Geological Society, Vol. 114, 1958, pp. 1-24. doi:10.1144/gsjgs.114.1.0001

[73] A. M. Quennell, “The Western Arabian Rift System," In: J. E. Dixon and A. H. F. Robertson, Eds., The Geological Evolution of the Eastern Mediterranean, Blackwell Scientific Publishers, Oxford, 1984, pp. 775-788.

[74] R. Freund, Z. Garfunkel, I. Zak, M. Goldberg, T. Weissbrod and B. Derin, "The Shear along the Dead Sea Rift," Philosophical Transactions of the Royal Society of London, Vol. 267, 1970, pp. 107-130.

[75] R. D. Hatcher, D. Zietz, R. D. Regan and M. Abu Majaeih, "Sinistral Strike-Slipmotion on the Dead Sea Rift, Confirmation from New Magnetic Data," Geology, Vol. 9, No. 10, 1981, pp. 458-462. doi:10.1130/0091-7613(1981)9<458:SSMOTD>2.0.CO;2

[76] R. W. Girdler and P. Styles, "Opening of the Red Sea with Two Poles of Rotation-Some Comments," Earth and Planetary Science Letters, Vol. 33, No. 1, 1976, pp. 169172. doi:10.1016/0012-821X(76)90169-2

[77] S. S. Richardson and C. G. A. Harrison, "Opening of the Red Sea with Two Poles of Rotation," Earth and Planetary Science Letters, Vol. 33, No. 1, 1976, pp. 135-142. doi:10.1016/0012-821X(76)90016-9

[78] R. W. Girdler, "Problems Concerning the Oceanic Lithosphere in Northern Red Sea," Tectonics, Vol. 116, No. 1-2, 1985, pp. 109-122.

[79] J. L. Labrecque and Zittellini, "Continuous Sea Floor Spreading in Red Sea, an Alternative Interpretation of Magnetic Anomaly Pattern," American Association of Petroleum Geologists, Vol. 69, 1985, pp. 513-524.

[80] M. L. Keeley, "Phanaerozoic Evolution of the Basins of Northern Egypt and Adjacent Areas," Geologische Rundschau, Vol. 83, No. 4, 1994, pp. 128-142. doi:10.1007/BF00251071

[81] A. S. El Hawat, "Sedimentary Basins of Egypt: An Overview of Dynamic Stratigraphy," In: R. C. Selley, Ed., African Basins. Sedimentary Basins of the World, Elsevier,
Amsterdam, 1997, pp. 39-85.

[82] A. Mosconi, A. Rebora, G. Venturino, P. Bocc and M. H. Khalil, "Egypt-Nile Delta and North Sinai Cenozoic Tectonic Sepaevolutionary Model: A Proposal," Proceedings of the 13th Petroleum Conference, Egyptian General Petroleum Corporation, Cairo, 1996, pp. 203-223.

[83] I. M. Hussein and A. M. A. Abd-Allah, "Tectonic Evolution of the Northeastern Part of the African Continental Margin, Egypt," Journal of African Earth Sciences, Vol. 33, No. 3-4, 2001, pp. 49-68. doi:10.1016/S0899-5362(01)90090-9

[84] A. R. Moustafa, R. EL-Badrawy and H. Gibali, "Prevasive E-ENE Oriented Faults in Northern Egypt and Their Effect on the Development and Inversion of Prolific Sedimentary Basins," EGPC 14th Exploration and Production Conference, Cairo, 1998, pp. 51-67.

[85] A. R. Moustafa, M. A. Yehia and S. Abdel-Tawab, "Structural Setting of the Area East of Cairo, Maadi, and Helwan," Middle East Research Center, Arn Shams University, Cairo, 1985, pp. 40-64.

[86] A. R. Moustafa and M. H. Khalil, "Rejuvenation of the Eastern Mediterranean Passive Contrnental Margin in Northern and Central Sinai: New Data from the Themed Fault," Geological Magazine, Vol. 131, No. 4, 1994, pp. 435-448. doi:10.1017/S0016756800012085

[87] Z. Garfunkel, G. H. Goudarzi, M. J. Salem and M. T. Busrewil, "Structure-Libya," Al-Fateh University, Libya, 1980, pp. 879-892.

[88] A. El-Sayed, F. Vaccari and G. F. Panza, "Deterministic Seismic Hazards in Egypt," The Abdus Salam International Centre for Theoretical Physics, United Nations Educational Scientific and Cultural Organization and International Atomic Energy Agency \& Trieste University, Trieste, 1999.

[89] A. Badawy, "Status of the Crustal Stress in Egypt as Inferred from Earthquake Focal Mechanisms and Borehole Breakouts," Tectonophysics, Vol. 343, No. 1-2, 2001, pp. 49-61. doi:10.1016/S0040-1951(01)00199-8

[90] A. Badawdy, "Present Day Stress Field in Egypt," Annali di Geofisica, Vol. 44, No. 3, 2003, pp. 45-56.

[91] K. M. Abou Elenean, "Focal Mechanisms of Small and Moderate Size Earthquakes Recorded by the Egyptian National Seismic Network (ENSN), Egypt," NRIAG Journal of Geophysics, Vol. 6, No. 1, 2007, pp. 119-153.

[92] N. N. Ambraseys, "The Seismicity of Southern Asia," Fifteenth Century Arabic Manuscript: Revue pour l'Etude des Calamites, Geneve, No. 37, 1961, pp.18-30. 